\title{
The Design of WeChat Teaching Platform Based on Flipped Classroom under the Background of Internet Plus
}

\author{
Ruifeng Wang \\ Shandong College of Electronic Technology
}

\begin{abstract}
Under the "Internet plus" background, the wave of mobile Internet spawned mobile Internet and mobile teaching, and teaching is the future trend of development. WeChat is born for the mobile Internet. WeChat platform can break the traditional teaching mode, realize the flipped classroom, making the traditional classroom teaching need knowledge into micro video, pushed to the students learning, class time is mainly used for teacher-student interaction. We based on the connotation of "Internet plus" and the core features in-depth analysis, put forward the necessity of teaching platform for the establishment of WeChat "Internet plus" under the background of the analysis, the function module of WeChat platform, and with "website construction and management" course as an example, the design of the teaching platform of the course. This innovative, subversive teaching platform will have a profound impact on teaching. With the use of WeChat's students increased, the value of education in the teaching of WeChat gradually reflected. WeChat will promote the rational use of fragmented time students, improve the teaching level of teachers, realizing the informatization of education has a positive meaning, provides a new platform for promoting the transformation of the mode of teaching and learning.
\end{abstract}

Keywords-Internet plus; flip the classroom; WeChat public number; teaching platform

\section{INTRODUCTION}

"Internet plus" is a new generation of information technology in cloud computing, big data and artificial intelligence as the representative of the "+" catalysis is the representative of the Internet to various other industries, through the new form of the Internet to detonate the [1] reform and the development of traditional industries. In November 2015 , the "forum on the development of Internet plus" and the occupation education information held in Beijing. The forum conducted in-depth discussion on the "Internet plus" and the occupation education informatization construction, "Internet plus" will bring a historic opportunity for the development of occupation education. In the course of the implementation of the flipped classroom, the making and pushing of the computer and video learning resources, the examination of the learning effect and the construction of the WeChat teaching platform are all the necessary conditions to carry out the flipped

Ruifeng-Wang(1974 -), female, Shandong, Jinan, master, lecturer. Main research interests: computer education, cloud computing

Project supported by the "13th Five-Year" national education science research project "the research on Higher Vocational Education Internet plus" (J16WG35)and the Shandong technological innovation project "Students' access to school management cloud platform" (201611901157) classroom. That is to say, turning the classroom needs to rely on the support of the information technology environment, and it needs the support of Internet and modern media technology to realize it better.

In recent years, in the "Internet plus" era, many scholars at home and abroad explore the impact of new technology on education. The first generation of education is centered on books, the second generation of education is centered on textbooks, and the third generation of education appears in the form of counselling and case studies. The fourth generation of education today is truly centered on students. Jingwen-Li, a member of the Chinese Academy of engineering, indicated that China's education is moving towards the 4 times. "Internet plus" will not replace the traditional education, it will bring the traditional education radiate new vitality.

\section{QUESTION RAISED}

\section{A. "Internet plus" Education}

"Internet plus" is a new form of information era. The Internet technology and thinking is to integrate various resources, to achieve a more efficient allocation of resources, improve the quality of products and services to facilitate the most effective way. As a national program, "Internet plus" is to play the advantages of the Internet, the Internet and traditional industries depth integration, to enhance the economic productivity of industrial upgrading, increase the social wealth. " Internet plus" education can be understood from two aspects: on one hand, can be understood as the Internet and traditional education or joint fusion, in order to achieve the purpose of education reform; on the other hand, can be understood as a complete educational reform through the traditional education of the internet. Therefore, the "Internet plus" education is the use of Internet technology and the Internet thinking, realize the integration of Internet and traditional education, update the concept of education, teaching environmental education reconstruction, reset the teaching mode, improve teaching efficiency and teaching quality, achieve the purpose of creative education [2]. The operation mode of "Internet plus" education, take the students and their experience as the core, give students the education status. 


\section{B. Flipped classroom}

The flipped classroom is based on the "Internet plus" the wisdom of teaching under the environment of a new type of teaching mode. It is a concrete manifestation of the Internet thinking in the teaching process, the integration of direct teaching and flipped classroom constructivist learning, classroom teaching and network learning, autonomous learning and collaborative learning in different modes, so that teachers, students and classroom have a fundamental change [3]. Flip the classroom, teachers are responsible for the construction teaching resources, for example micro class video etc., curriculum resources for students to complete learning before class. Teachers and students in the classroom discussion, answering questions, explore the teaching activities and complete the task of teaching. Text, PPT courseware and micro video are usually the learning resources before class in the flipped classroom. Students understand through the autonomous learning of the new knowledge, to improve students' knowledge before class preparation results, to get into "do" and "use" components. So students' pre - class learning is changed to learning through tasks rather than just watching videos. In the evaluation of communication, students will be their own innovation points and show their more distinctive features and pay attention to improve the effect of learning.

\section{WeChat teaching platform}

With the rapid development of mobile Internet, the information environment is constantly optimized, and the ways of teaching and learning are changing greatly. In recent years, mobile technology has been listed as an important technology in the field of education with potential for development and application space. With the emergence of the WeChat public number and service number, WeChat entered the field of education. From the traditional classroom to the intelligent classroom, and then to the intelligent teaching environment, the development process is not only a change in the form of teaching, but also a change in the teaching philosophy which is promoted by technology. The relationship between teachers and students in teaching environment is the wisdom of equality and interaction. Teaching resources are build and used by the teachers and students together. The wisdom teaching environment of the software and hardware resources are set to "learn", such as flipping the classroom are student-centered teaching mode. Through the WeChat, teaching platform can break the traditional teaching mode, realize the flipped classroom, and make the traditional classroom teaching need knowledge into micro video, and push to the students learning under class. Class time is mainly used for teacher-student interaction.

Mobile App is the best form of instruction, which has a long development cycle and high development and maintenance costs. And WeChat's use experience is really good, and its social interaction features can also meet some of the basic needs of mobile teaching, so WeChat teaching shows a strong vitality. With the widespread popularity of WeChat, WeChat has been used by many companies to carry mobile teaching, and enterprises and schools trying to teach WeChat are still increasing. Although more and more studies have been carried out with WeChat, research has been carried out from theory.

\section{WECHAT TEACHING PlATFORM}

"Internet plus" on the field of teaching mainly in the following four aspects: firstly, teaching resource management, the most widely used in flipped classroom is able to "inspire, influence and inform" the role of the micro video, teachers give students before class to see the text material or multimedia materials can't arouse the interest of students. It doesn't have a good learning effect which leads to the failure of classroom knowledge, fails to flip classroom. Micro video convert static data for digital learning vivid, educational, creative, thoughtprovoking, understandable, and exciting the massive open online video courses. Teaching effect is greatly improved. The teachers' teaching habits of the teacher on the podium fight the wisdom of education; the students' learning more personalized, diversified and fragmented. In terms of knowledge structure, it further integrates. In terms of cost, we can reduce the cost of education input through the advantages of public service platform and teachers themselves. Face to face will not disappear, but it can improve the efficiency of teaching.

WeChat refers to the teaching platform of WeChat public platform based on the platform of teaching and learning for teachers and students, according to different disciplines, teachers use their own advantages to participate directly in the application of the design and Realization of modernization of education, social and mobile. WeChat Public Platform 2015 fully open 11 class interface, web development kit JS-SDK, allowing WeChat public platform interface access through third party server, Web-APP development based on WeChat have been fully activated. All connected to the development trend of WeChat Unlimited Web links to jump to other teaching, greatly broadens the WeChat teaching platform resources and storage space. The students get a better user experience and more learning fun.

Combined with the design of teaching process teaching platform of WeChat "website construction and management", this course is a professional course of the close combination of theory and practice, learn to teach the class with the integration condition, with WeChat teaching platform can effectively solve the problem of less teaching hours, the practice time is short. For example, the original curriculum of the class is the main way, teachers finished steps, students practice after students by the teachers, then to submit to teacher's computer. The teacher selects and evaluates and shows the representative works. Because there is no more time in class, to show their works, discuss and give the evaluation of student work. With the help of WeChat teaching platform, it can increase the time and enthusiasm of the students' pre class preparation, class interaction, display and evaluation, and can promote the overall development and progress of students, and further enhance the teaching effect.

\section{Wechat Teaching Platform NeEds Analysis}

WeChat teaching platform can basically meet the needs of the flipped classroom. The preparation stage before class, teaching objectives, case, micro video data are uploaded. Students can watch them. Teachers and students can be through 
the mobile phone to sweep the two-dimensional code for class to answer in class. After the submission the correct rate of each of the questions and answers can be displayed on large screen display with interactive results. Through the mobile phone, students can upload their own the website of the creative and production effect. Students can comment on mutual praise. Teachers can comment on a student's work. After class, teachers can direct private message on homework or consult results when students, inform the work or provide more detailed learning methods that targeted to help students quickly improve the learning achievement; so the platform connects before class, in class and after class, make the perfect combination of online and offline.

WeChat teaching platform can provide classroom attendance, sweeping, interactive discussion and evaluation function. Such as sweep interaction not only support kinds of questions of the design on the choice, judgment, simply fill in the blanks, but also support tests online editing and publishing services. Teaching resources management is more efficient and convenient for flipping the classroom. Many other video resources are uploaded and downloaded. It provides communication across time and space platform for the implementation of the interactive classroom teaching activities turn.

By using the third party data interface provided by WeChat public number, the common functions of material management, bulk messaging and user message reply are achieved. For example, the teacher can push the update messages to all students or some students and quickly update the notifications, teaching contents and so on to each student's mobile phone. The curriculum requirements for students in a knowledge point or a topic of study. The lower end of the target with micro video teaching is more appropriate, and analysis, high level of cognitive objectives in the synthesis and evaluation of classroom teaching can be arranged in turn in the teachers and students interact to complete.

In short, sweep using a mobile phone at any time organizing interactive discussion, interactive results synchronous display with a large screen, gave everyone a chance to speak with the full depth of thinking; teaching content from the micro video playback, image, intuitive, convenient, more suitable for "website construction and management" course; learning via WeChat is a kind of brandnew teaching platform experience in following the course learning at the same time, will have a personalized learning path and immediate feedback; face will not disappear, but can improve the efficiency.

\section{Function Design of Wechat Teaching Platform}

First of all, the communication platform, including many people chat, video calls, language calls and other forms, through chat, video and so on to strengthen the collaboration between teachers and students, students and students. Next is the open platform, may realize the teaching content sharing and the teaching resources sharing. Through the circle of friends, micro communities issued their own topic, you can also classify topics, browse, comment on other people's topic. Finally, WeChat public platform, through subscription push function, can be grouped according to different levels of students, respectively, to send different teaching content. The teaching materials uploaded by teachers are stored in the material library, and students click on them immediately. The students also watch micro videos in the micro courses. The public platform can also count the number of users, the number of readers and the number of forwarding, etc., analysis of students in a period of time issued by the state of the map, so that teachers more detailed understanding of student participation. WeChat teaching platform with the basic functions of WeChat public platform and interface to achieve, the following focus on the WeChat teaching platform features design.

Through the analysis of WeChat and the diversified functions of teaching activities support, combined with the characteristics of "Internet plus", designed a practical teaching platform of WeChat. Thinking of the Internet is through WeChat teaching platform, menu and function of the platform are shown in table 1 . The WeChat platform is mainly used by teachers and students. Teachers as a teaching platform of WeChat administrator login the backstage management interface. They can be selectively used according to the needs of teaching platform, design the teaching aim and content, suitable for editing and management platform. Students visit the mobile phone user interface; they can access and manage learning content, and interact with teachers.

TABLE I. FUNCTION INTRODUCTION OF MAIN MENU AND SUBMENU

\begin{tabular}{|c|c|c|}
\hline $\begin{array}{l}\text { Main Menu } \\
\text { Name }\end{array}$ & $\begin{array}{l}\text { Submenu } \\
\text { Name }\end{array}$ & Function Introduction \\
\hline \multirow{3}{*}{$\begin{array}{l}\text { Teaching } \\
\text { resources }\end{array}$} & FAQ & FAQ \\
\hline & $\begin{array}{l}\text { Teaching } \\
\text { objectives }\end{array}$ & Teaching objectives of each project \\
\hline & $\begin{array}{l}\text { Micro } \\
\text { courses }\end{array}$ & $\begin{array}{c}\text { Complete curriculum video, project } \\
\text { decomposition of each video is not more than } \\
\text { ten minutes }\end{array}$ \\
\hline \multirow{5}{*}{$\begin{array}{l}\text { Teaching } \\
\text { interactive }\end{array}$} & Attendance & $\begin{array}{l}\text { GPS positioning, used for class naming, } \\
\text { master class attendance }\end{array}$ \\
\hline & $\begin{array}{l}\text { Sweeping } \\
\text { interaction }\end{array}$ & $\begin{array}{c}\text { Through scanning two-dimensional code, you } \\
\text { can use the mobile phone class answer, after } \\
\text { submission, you can display the correct rate } \\
\text { of each question and the correct answer, } \\
\text { synchronized display of large screen } \\
\text { interactive results }\end{array}$ \\
\hline & $\begin{array}{l}\text { Micro } \\
\text { creative }\end{array}$ & $\begin{array}{l}\text { Micro login users can publish map creative } \\
\text { and effective website, you can also view the } \\
\text { creativity of others, can give some praise and } \\
\text { evaluation of their own creative works of } \\
\text { love }\end{array}$ \\
\hline & Micro forum & $\begin{array}{l}\text { Users can all users in the forum each one airs } \\
\text { his own views, can participate in the } \\
\text { discussions, give advice and suggestions }\end{array}$ \\
\hline & $\begin{array}{c}\text { Online } \\
\text { questions and } \\
\text { answers }\end{array}$ & $\begin{array}{c}\text { An intelligent database system for online } \\
\text { questions and answers for users to find } \\
\text { questions and answers }\end{array}$ \\
\hline \multirow{5}{*}{$\begin{array}{l}\text { Personal } \\
\text { center }\end{array}$} & $\begin{array}{r}\text { Teacher } \\
\text { entrance }\end{array}$ & $\begin{array}{c}\text { Teacher login backstage management } \\
\text { interface entrance }\end{array}$ \\
\hline & $\begin{array}{c}\text { Score } \\
\text { inquiries }\end{array}$ & $\begin{array}{c}\text { Score inquiries, providing results query } \\
\text { entrance }\end{array}$ \\
\hline & $\begin{array}{l}\text { My micro } \\
\text { lesson }\end{array}$ & Record the history of a link of you browsed \\
\hline & $\begin{array}{c}\text { My } \\
\text { interaction }\end{array}$ & My interaction records personal interactions \\
\hline & $\begin{array}{l}\text { Personal } \\
\text { experience }\end{array}$ & Record your personal experience \\
\hline
\end{tabular}


The WeChat teaching platform is designed into three modules: teaching resource module, teaching interaction module and personal center module.

\section{A. Teaching resource module}

The module is mainly for students to learn the teaching resources. Resource release, teaching resources will be deployed in the cloud storage system, help to improve resource utilization and user access speed, enhanced platform scalability and user experience, so that students can view real-time teaching resources on any device. In addition, the teaching resources include preset resources and generative resources. The preset resources are set by teachers, and the generative resources are generated with the development of curriculum. This part of the resources is mainly for students to study by themselves, which can be used to preview or review lessons.

\section{B. Teaching interactive module}

The module includes attendance, scanning, interactive, micro creative, micro forums, and online questions. The module can reverse the classroom. First of all, through the attendance function, teachers can timely access to students in class attendance. They can achieve classroom testing with the use of sweeping interaction, real-time control of students' learning status and learning effect [4]. According to the "website construction and management" course before the students have been studying the course of micro video teaching resources, teachers do not have to lectured to his students. The original time for face-to-face interaction, it is mainly mechanical teacher speaking, students listening passively, the interaction between teachers and students or students and students are discussed. Micro creativity, create a web effect of the display window, with a display of stage effect to the students' website platform, published map creation and performance site, you can also view the creativity of others, can give their point of praise and love the creative works of peer assessment, participation track record of students, the formation of evaluation is an important part of. Because the student's role change, in the extremely relaxed joyful atmosphere, grasps the knowledge firmly, before the class micro video does not understand the question to understand, has aroused student's classroom study and the participation enthusiasm enormously. After class is limited, in the classroom more than I do not complete the problems and knowledge points, you can class through micro forums, online questions and other ways of communication. This not only activates the students' enthusiasm for classroom research, but also creates the extracurricular learning mechanism of students. It can also be discussed and demonstrated with the teachers and students of their counterparts and other institutions of higher learning. The online answering system uses automatic reply and intelligent reply, which is a database system for users to find questions and answers. Intelligent database system can avoid repeated reply teachers to answer the same questions, when students present a problem, WeChat teaching platform will automatically give a similar answer for students. If the students are not satisfied with this answer, then they can wait for the teacher to answer after answer. This system will issue as a new data is added to in the database, so that other students use.

\section{Personal central module}

The module includes the teacher entrance, the results of inquiries, my micro class and my interaction. The teacher entrance is the two main functions of the teacher's publication, resource management and student entrance, resource retrieval and online question answering. Results enquiries provide the results of all kinds of tests, including class performance and final results. My micro lessons and my interaction record individual videos and interactions. Personal learning in the journal is recorded.

\section{CONCLUSION}

Based on the discussion of the "Internet plus" and flipping the classroom, teaching the general public platform with the WeChat and extended functions, put forward a course specific teaching platform based on WeChat. The platform is a new type of teaching service platform. It runs through the whole process of teaching and learning. Provide class management and convenient micro video sharing, online testing and results are published and creative website and effect of summary and analysis, discussion service module for teaching. It is with the operating system from WeChat public platform restrictions, easy to operate, compared with the same kind of teaching management service platform, the most prominent feature of this platform is the effect of classroom interaction, teaching service module can satisfy the basic needs of the flipped classroom. But the platform is just a computer teacher, combined with his personal experience to design the class, if further development, to promote more comprehensive consideration and design, and with new media technologies continue to emerge, there will be new demand. Therefore, we should combine the new technology and new ideas with actual problems encountered, further optimize the functions of WeChat teaching platform, and constantly improve in practice, and promote the development of China's educational information technology.

\section{REFERENCES}

[1] Qiaofeng- Wang, Xiaoying -Cao, $\mathrm{Lu} \mathrm{Lu} "$ ". The development of Internet plus education mode analysis of [J]. China education information, 2015, (15): 10 .

[2] Nanzhong -Wu, "Internet plus education connotation and mechanism for promoting [J]. adult education, 2016 (1): 7.

[3] (USA), Jonathan, Aaron. Flipped class and Mu class teaching [M] Beijing: Chinese Youth Press, 2013:158.

[4] Beijing excellent screen technology Co., Ltd., UMU interactive learning platform, https://www.umu.cn/model/home. 